\title{
MODEL HUBUNGAN ANTARA KONDISI FUNGSIONAL DENGAN KONDISI STRUKTURAL SEBAGAI ESTIMASI KONDISI PERKERASAN PADA JALAN NASIONAL DI SULAWESI SELATAN DAN KALIMANTAN SELATAN
}

\author{
Androsario Sarimuda Wasta ${ }^{1}$, Miftahul Fauziah ${ }^{2}$, Subarkah $^{3}$ \\ ${ }^{1}$ PT Waskita Karya Jakarta, \\ Email : sswandro@yahoo.com \\ ${ }^{2}$ Program Studi Teknik Sipil, Universitas Islam Indonesia, Yogyakarta \\ Email : miftahul.fauziah@uii.ac.id \\ ${ }^{3}$ Program Studi Teknik Sipil, Universitas Islam Indonesia, Yogyakarta \\ Email : subarkah@uii.ac.id.
}

\begin{abstract}
The limitations of Falling Weight Deflectometer (FWD) for measuring structural conditions of road pavement in Indonesia have led to measurements of road conditions to be sufficient only for the assessment of functional conditions. Based on this reason, the model of the relationship between functional conditions and structural conditions of pavement becomes a needed. This paper presents study of the correlation model between functional parameters based on IRI with the elastic modulus of the pavement layer. Data was obtained from the Central National Road Implementation Center (BBPJN) and the National Road Implementation Center (BPJN) of South Kalimantan and South Sulawesi Provinces. In the Province of South Kalimantan, road surface roughness (IRI) has a level of correlation that adequately represents the elastic modulus of the surface layer (E1), but has a low correlation with the elastic modulus of the base layer (E2), subbase layer (E3) and underground layer (E4)). Surface roughness (IRI) on roads in South Sulawesi has a degree of correlation that represents the modulus of the surface layer elasticity (E1), and the base layer (E2), but does not represent the elastic modulus of the subbase (E3) and subgrade (E4).
\end{abstract}

Keywords: International Roughness Index, Falling Weight Deflectometer, ELMOD, Elastic Modulus, Surface Layer.

\section{PENDAHULUAN}

Kondisi penanganan pemeliharaan jalan di Indonesia masih belum sepenuhnya akurat karena tidak didukung oleh pemeriksaan kondisi jalan yang lengkap. Pemeriksaan kondisi jalan untuk menentukan penanganan pemeliharaan jalan lebih cenderung menggunakan data pemeriksaan kondisi fungsional, disebabkan karena alat untuk pemeriksaan kondisi struktural tidak dimiliki oleh semua provinsi di Indonesia. Keterbatasan persediaan alat Falling Weight Deflectometer (FWD) untuk pengukuran kondisi struktural perkerasan jalan menyebabkan banyak pengukuran kondisi jalan hanya mencukupkan pada penilaian kondisi fungsionalnya saja. Berdasar alasan ini, model hubungan antara kondisi fungsional dengan kondisi struktural perkerasan jalan menjadi sangat diperlukan. Model yang diperoleh dapat membantu mengestimasi dan memprediksi kondisi fungsional jalan berdasarkan hasil hasil pengukuran kondisi fungsional yang sudah ada.

Pengukuran kondisi fungsional perkerasan yang cukup mudah dan umum dilakukan adalah dengan pengukuran nilai IRI (International Roughness Index), yang dikembangkan oleh Bank Dunia. Nilai IRI digunakan untuk menggambarkan suatu profil memanjang dari suatu jalan dan digunakan sebagai standar ketidakrataan permukaan jalan, yang dihitung dari jumlah kumulatif naik turunnya permukaan arah profil 
memanjang dibagi dengan jarak/ panjang permukaan yang diukur. Satuan yang umum direkomendasikan adalah meter per kilometer $(\mathrm{m} / \mathrm{km})$ atau milimeter per meter $(\mathrm{mm} / \mathrm{m})$.

Kajian tentang hubungan antara kondisi fungsional dengan kondisi struktural jalan belum cukup banyak diteliti dan dipublikasikan sebelumnya. Studi korelasi antara ketidakrataan permukaan jalan berdasar nilai IRI dengan indeks kondisi Jalan berdasar nilai $R C I$, Studi Kasus Ruas Jalan Labuan-Cibalung pernah dipublikasikan oleh Suherman (2008). Pada penelitian tersebut diperoleh persamaan korelasi antara parameter ketidakrataan permukaan jalan berdasarkan nilai IRI dengan metode NAASRA yang sangat berkorelasi kuat dengan indeks kondisi jalan berdasarkan nilai RCI (Road Condition Index). Hasil penelitian tersebut menghasilkan korelasi yang cukup berbeda dengan hasil hasil kajian sebelumnya, oleh Paterson (1987), maupun Parera (1998) yang telah lebih dulu mempublikasikan hasil penelitiannya. Kajian sejenis juga telah dilakukan baru baru ini oleh Utama dan Farida (2016), yang mencari model hubungan IRI dan $R C I$, studi kasus pada Ruas Jalan Selajambe-Cibogo-Cibeet, Cianjur. Studi hubungan antara nilai kerusakan dengan metode $P C I$ dengan nilai IRI pada Jalan Propinsi UPT Mojokerto juga telah diteliti oleh Prabowo, dkk. (2006), sedangkan Kartika (2013) meneliti pengaruh nilai IRI terhadap nilai kerusakan jalan Tol Surabaya Gempol dan Zeahsa, (2015) juga mengkaji model hubungan IRI dan Surface Distress Index (SDI) pada perkerasan. Kajian tentang korelasi antara IRI dengan $R C I, S D I$ maupun PCI, serta angka kerusakan jalan dari studi studi tersebut masih mengkorelasikan antara parameter fungsional dengan parameter fungsional jalan lainnya, namun belum mengkaji kondisi struktur jalan.
Berbeda dengan hasil studi studi sebelumnya, paper ini menyajikan kajian model korelasi antara parameter fungsional berdasar nilai IRI dengan nilai struktural, berdasar nilai modulus elastis lapisan perkerasan. Metode yang digunakan adalah Bina Marga (Kementerian Pekerjaan Umum, 2011) untuk analisis kondisi fungsional dan AASHTO (1993) untuk analisis nilai struktural perkerasan (Kementerian Pekerjaan Umum, 2009).

\section{METODE PENELITIAN}

\section{Pengambilan Data}

Data yang digunakan dalam penelitian ini diperoleh pada tahun 2014 dari Balai Besar Pelaksanaan Jalan Nasional (BBPJN). Data dari Provinsi Sulawesi Selatan diperoleh dari wilayah kerja BBPJN VI sedangkan data dari Provinsi Kalimantan Selatan diperoleh dari wilayah kerja BPJN VII.

Data yang diambil berupa data kondisi permukaan jalan Nasional berdasar nilai IRI (International Roughness Index), yang diperoleh dari survei dengan alat Roughness meter NAASRA (Kementerian Pekerjaan Umum, 2011). Berdasar metode AASTHO 1993, data lendutan jalan yang menunjukkan kondisi struktural jalan, dihasilkan dari pengujian dengan alat FWD (Falling Weight Deflectometer). Nilai $F W D$ diinput menggunakan software ELMOD untuk mendapatkan nilai modulus elastisitas tiap-tiap lapis perkerasan (Hardwiyono, 2012)

Data dari tiap provinsi sebanyak empat ruas, untuk Provinsi Sulawesi Selatan yaitu ruas 007, 005, $00111 \mathrm{~K}, 00614 \mathrm{~K}$, sedangkan untuk Provinsi Kalimantan Selatan yaitu ruas 006, 007010 dan 010 $11 \mathrm{~K}$.

Berdasar nilai IRI yang telah diperoleh, dan nilai modulus elastis tiap lapis hasil pengolahan data dengan software $E L M O D$, dilakukan analisis regresi untuk mengetahui korelasi antara nilai IRI 
dengan nilai $\mathrm{E}$ tiap lapisan, dalam bentuk persamaan regresi, serta koefisien determinasi dan korelasi.

\section{PEMBAHASAN}

\section{Model Hubungan antara Nilai IRI dengan nilai Modulus Elastisitas Lapis Perkerasan Jalan di Kalimantan Selatan}

Grafik korelasi antara nilai IRI dengan nilai modulus elastisitas lapis permukaan (E1) pada Jalan di Kalimantan Selatan disajikan pada Gambar 1.

Berdasar Gambar 1 dapat dilihat bahwa koefisien determinasi $\left(\mathrm{R}^{2}\right)$ dari grafik persamaan regresi model hubungan antara nilai IRI dan E1 lapisan surface yang paling besar adalah persamaan regresi Eksponensial dengan koefisien korelasi (r) sebesar 0,4631, yang menunjukkan tingkat hubungan yang tergolong "sedang" antara kondisi fungsional dan kondisi struktural lapis lapis permukaan. Tingkat hubungan tersebut mengindikasi bahwa kondisi modulus elastisitas lapis permukaan (E1) cukup berkorelasi dengan nilai IRI.

Pada Gambar 2 ditampilkan grafik hubungan antara nilai IRI dengan E2.
Koefisien determinasi $\left(\mathrm{R}^{2}\right)$ dari grafik persamaan regresi antara model hubungan IRI dan E2 lapisan lapis pondasi atas yang paling besar adalah persamaan regresi Polinomial dengan koefisien korelasi (r) sebesar 0,279, yang menunjukkan tingkat hubungan yang tergolong "lemah" antara kondisi fungsional dan kondisi struktural lapis pondasi atas. Tingkat hubungan tersebut mengindikasikan bahwa kondisi modulus elastistas lapis pondasi atas (E2) kurang berkorelasi dengan nilai $I R I$.

Plotting hubungan nilai IRI dengan nilai E3 dapat dilihat pada Gambar 3. Dapat dilihat dari grafik bahwa nilai koefisien determinasi $\left(\mathrm{R}^{2}\right)$ dari grafik persamaan regresi model hubungan antara IRI dan E3 (lapisan lapis pondasi bawah) yang paling besar adalah persamaan regresi Eksponensial dengan koefisien korelasi (r) sebesar 0,196, menunjukkan tingkat hubungan antara kondisi fungsional dan kondisi struktural lapis pondasi bawah yang dapat dikategorikan "sangat lemah". Hal ini mengindikasi bahwa kondisi modulus elastisitas lapis perkerasan bawah (E3) tidak dapat diprediksi dengan menggunakan nilai IRI.

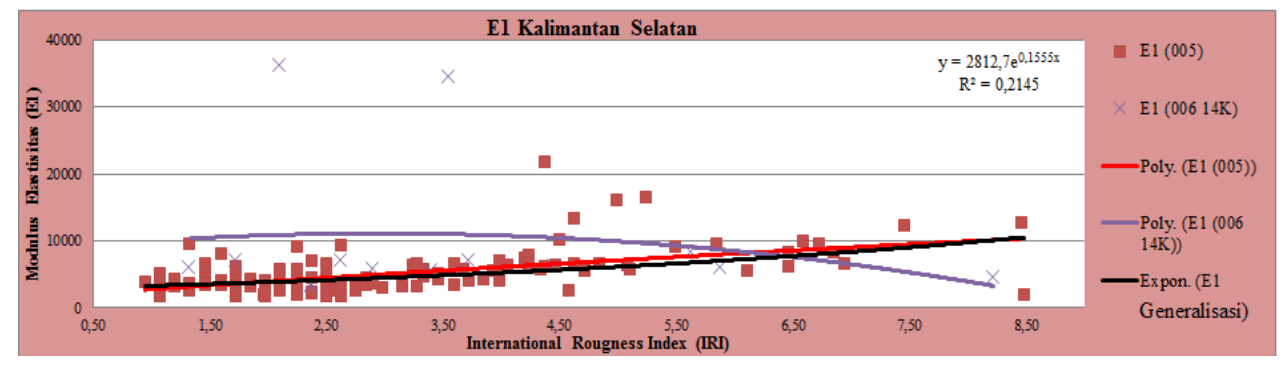

Gambar 1 Grafik korelasi eksponensial IRI dengan E1 Provinsi Kalimantan Selatan

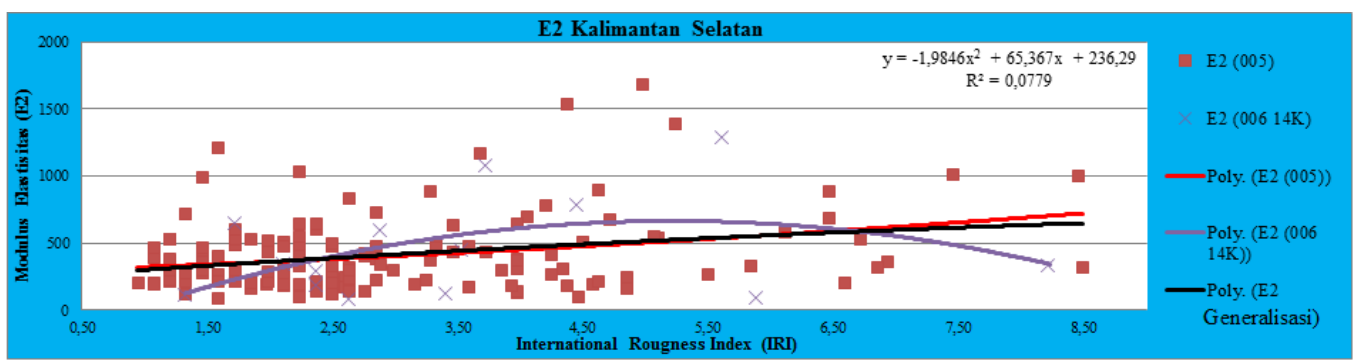

Gambar 2 Grafik polinomial korelasi antara nilai IRI dengan E2 Provinsi Kalimantan Selatan 


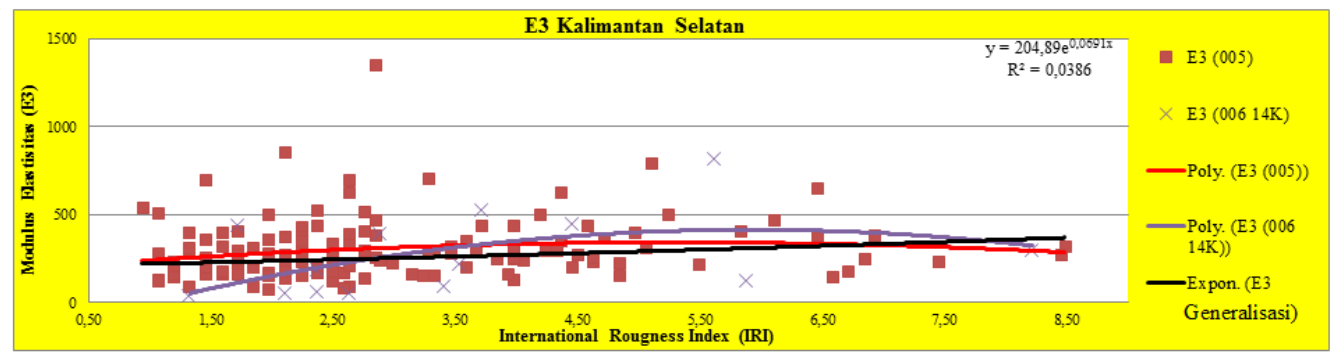

Gambar 3 Grafik eksponensial hubungan antara IRI dengan E3 Provinsi Kalimantan Selatan

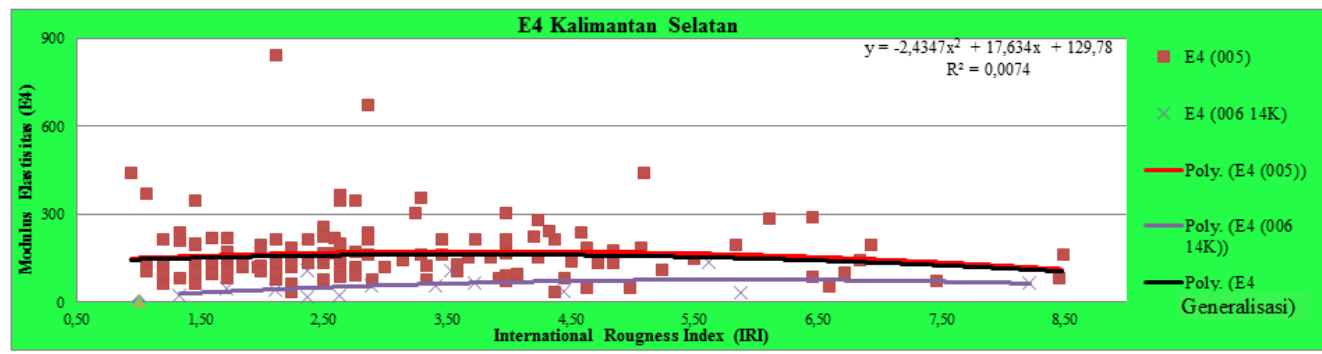

Gambar 4 Grafik eksponensial korelasi IRI dengan E4 Provinsi Kalimantan Selatan

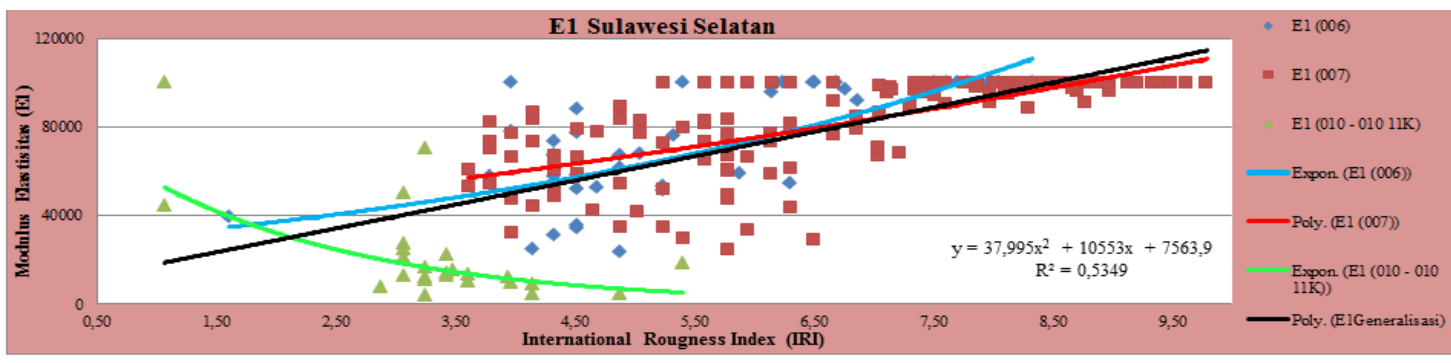

Gambar 5. Grafik polinomial hubungan antara RI dan E1 Provinsi Sulawesi Selatan

Gambar 4 memuat grafik korelasi nilai IRI dengan nilai E4 (lapis tanah dasar). Dapat dilihat dari gambar bahwa koefisien determinasi $\left(\mathrm{R}^{2}\right)$ dari grafik persamaan regresi model hubungan antara IRI dan E4 yang paling besar adalah persamaan regresi Polinomial dengan koefisien korelasi (r) sebesar 0,086 yang menunjukkan tingkat hubungan yang tergolong "sangat lemah" yang mengindikasikan bahwa nilai IRI tidak dapat digunakan untuk mengestimasi nilai modulus elastistas lapis tanah dasar (E4).

Model Hubungan Antara nilai IRI dengan nilai Modulus Elastisitas Lapis Perkerasan Jalan di Sulawesi Selatan

Korelasi antara nilai IRI dengan nilai E1 (lapis permukaan) pada Jalan di Provinsi
Sulawesi Selatan diplotkan pada Gambar 5. Dapat dilihat dari grafik tersebut bahwa nilai koefisien determinasi $\left(\mathrm{R}^{2}\right)$ dari grafik persamaan regresi model hubungan antara IRI dan E1 yang paling besar adalah persamaan regresi Polinomial dengan koefisien korelasi (r) sebesar 0,7313 yang menunjukkan tingkat hubungan yang tergolong "kuat" antara kondisi fungsional dan kondisi struktural lapis permukaan. Tingkat hubungan tersebut mengindikasi bahwa nilai modulus elastistas lapis permukaan dapat diprediksi karena memiliki korelasi yang kuat dengan nilai IRI. 


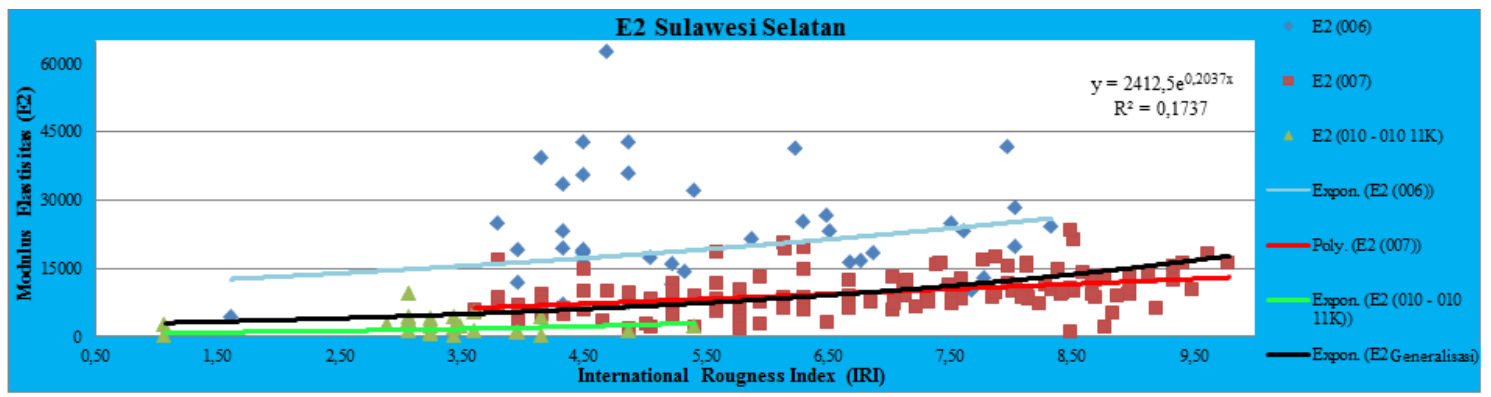

Gambar 6 Grafik eksponensial korelasi nilai IRI dengan E2 Provinsi Sulawesi Selatan

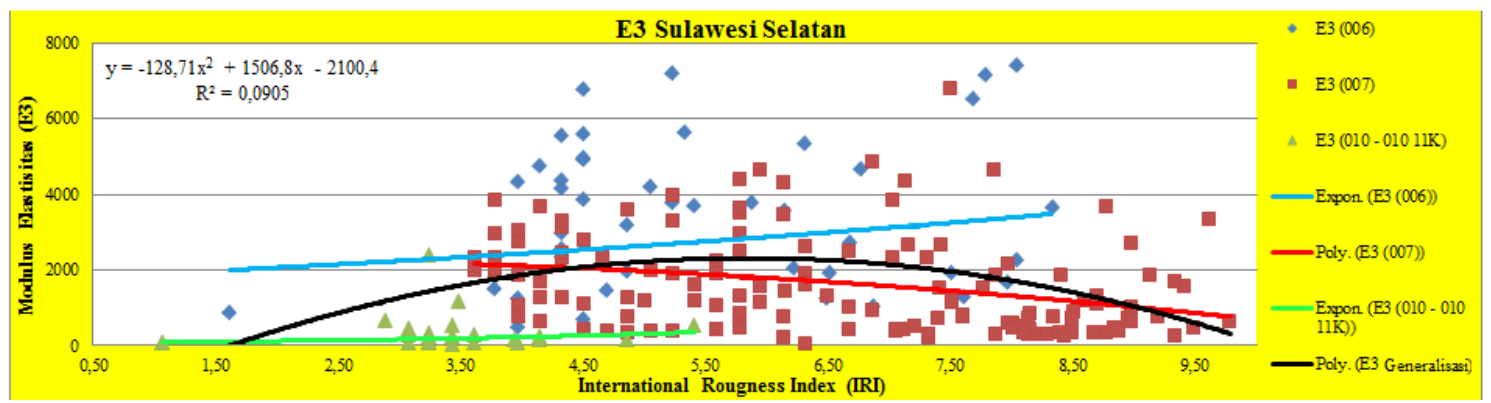

Gambar 7 Grafik polinomial hubungan antara Nilai IRI dengan E3 Provinsi Sulawesi Selatan

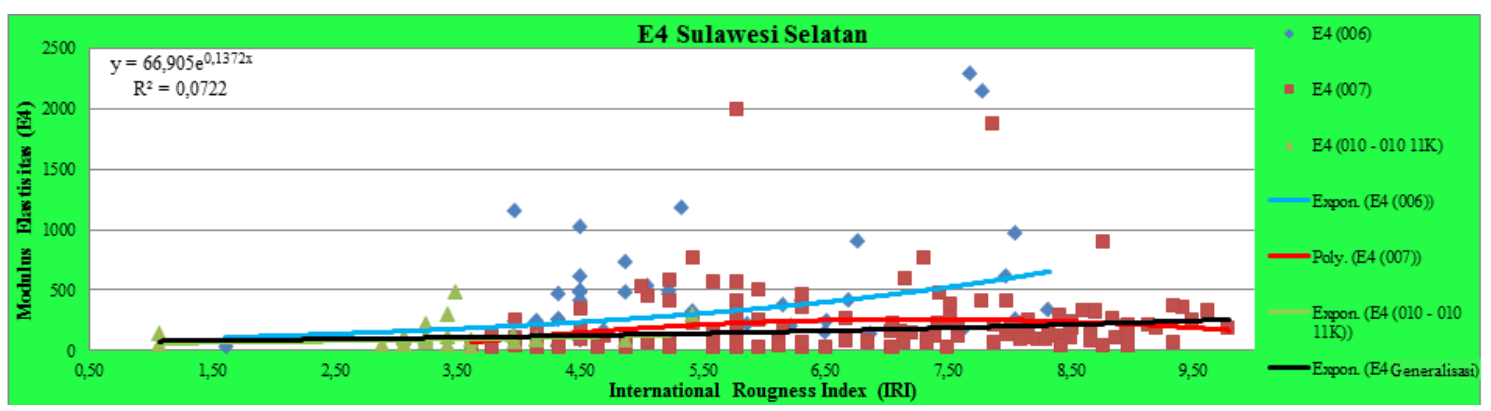

Gambar 8 Grafik Eksponensial Korelasi nilai IRI dengan E4 Provinsi Sulawesi Selatan

Gambar 7 menampilkan korelasi antara nilai IRI dengan nilai E3 (lapis pondasi bawah). Berdasar grafik tersebut dapat diketahui bahwa nilai koefisien determinasi $\left(\mathrm{R}^{2}\right)$ dari grafik persamaan regresi model hubungan antara $I R I$ dan E3 yang paling besar adalah persamaan regresi Polinomial dengan koefisien korelasi (r) sebesar 0,308 yang menunjukkan tingkat hubungan yang "lemah" antara kondisi fungsional dan kondisi structural lapis pondasi atas. Tingkat hubungan tersebut mengindikasi bahwa kondisi modulus elastisitas lapis pondasi bawah (E3) kurang berkorelasi dengan nilai IRI.
Hubungan antara nilai IRI dengan nilai E4 (tanah dasar) digambarkan pada Grafik 8. Dapat dilihat dari grafik tersebut bahwa nilai koefisien determinasi $\left(\mathrm{R}^{2}\right)$ dari grafik persamaan regresi model hubungan antara IRI dan E4 (lapis subgrade) yang paling besar adalah persamaan regresi Eksponensial dengan koefisien korelasi (r) sebesar 0,2687 yang menunjukan tingkat hubungan yang "lemah" antara kondisi fungsional dan kondisi struktural tanah dasar. Tingkat hubungan tersebut mengindikasi bahwa nilai modulus elastisitas lapis tanah dasar (E4) tidak dapat diperkirakan dengan menggunakan nilai IRI. 


\section{Indikasi Pengaruh Perbedaan Jenis dan Tebal Lapis Perkerasan}

Model hubungan regresi antara kondisi fungsional dengan kondisi struktural pada masing - masing lokasi memiliki hasil hubungan korelasi yang berbeda, terutama pada lapis permukaan (surface). Tabel 1 menunjukkan hasil rekapitulasi nilai E pada berbagai jenis material. Dapat dilihat dari tabel tersebut bahwa lapis permukaan (surface) yang menggunakan bahan AC (Asphalt Concrete) atau laston memiliki nilai modulus elastisitas (E) yang relatif lebih kecil dibandingkan dengan lapis permukaan yang menggunakan material HRS (Hot Rolled Sheet) atau lataston dan didukung lapis ATB (Asphalt Threated Base), yang memiliki nilai modulus elastisitas (E) yang lebih besar. Fakta tersebut mengindikasi adanya korelasi antara jenis perkerasan dengan nilai struktural perkerasan.

Penelitian Amrullah (2013), menyimpulkan bahwa karakteristik lapisan AC (Asphalt Concrete) lebih peka terhadap variasi kadar aspal maupun variasi gradasi agregat daripada Lataston $(H R S)$. Aspal Beton $(A C)$ terdiri dari tiga macam campuran, yaitu: Laston Lapis Aus $2(A C-W C)$, Laston Lapis Aus 1 $(A C-B C)$ dan Laston Lapis Pondasi $(A C$ $B a s e$, dengan ukuran maksimum agregat masing-masing campuran adalah $19 \mathrm{~mm}$, 25,4 $\mathrm{mm}$ dan 37,5 mm. Adapun lapisan HRS (Hot Roller Sheet) mempunyai persyaratan kekakuan yang sama dengan tipikal yang disyaratkan untuk aspal beton konvensional $(A C)$ yang bergradasi menerus. Lataston terdiri dari dua macam campuran, yaitu: Lataston Lapis Pondasi (HRS-Base) dan Lataston Lapis Permukaan (HRS Wearing Course) dengan ukuran maksimum agregat masing-masing campuran adalah $19 \mathrm{~mm}$. Pada Asphalt Treated Base (ATB) dengan tebal minimum lapisan $5 \mathrm{~cm}$ digunakan sebagai lapis pondasi atas konstruksi jalan dengan lalu lintas berat / tinggi.
Berdasar rekapitulasi yang ditampilkan Tabel 1, dapat dipelajari bahwa selain jenis lapisan perkerasan jalan, juga terdapat pengaruh dari tebal lapisan perkerasan jalan terhadap besaran modulus elastisitas yang dihasilkan. Semakin tipis tebal lapis perkerasan pada ruas jalan tersebut maka nilai korelasi kerusakan akan semakin mengikat ke bawah dari lapisan pondasi atas, menuju lapisan pondasi bawah, dan lapisan tanah dasar, yang selanjutnya korelasinya bergantung pada tebal dan jenis dari masing-masing lapisan. Tebal lapis permukaan ruas jalan dengan jenis lapisan $A C$ rata-rata $(5-24 \mathrm{~cm})$ mengindikasi lendutan menghasilkan nilai modulus elastisitas lapis permukaan (E1) berkisar 1500-30000 Mpa, dengan tingkat hubungan yang "sedang". Ketika lendutan mentransfer ke bawah menuju lapis pondasi atas, nilai modulus elastisitas (E2) menjadi semakin "lemah" menjadi berkisar antara 100-1500 Mpa, dengan ketebalan rata-rata $(10-20 \mathrm{~cm})$. Nilai modulus elastistas lapis pondasi bawah (E3) dan modulus elastisitas lapis tanah dasar (E4) semakin "sangat lemah", masing-masing berkisar antara 10-800 Mpa, dengan tebal lapisan masing-masing $(5-30 \mathrm{~cm})$ dan $(5-85 \mathrm{~cm})$. Dibandingkan dengan tebal lapis permukaan, lapisan $H R S$ yang didukung lapis $A T B$ rata-rata $(5 \mathrm{~cm}-7 \mathrm{~cm})$ menghasilkan nilai modulus elastisitas lapis permukaan (E1) sebesar 3000$100000 \mathrm{Mpa}$, dengan tingkat hubungan yang "kuat". Ketika lendutan mentransfer ke bawah menuju lapis pondasi atas, nilai modulus elastisitas (E2) menjadi semakin berkurang dengan kategori "sedang", dengan nilai $100-60000 \mathrm{Mpa}$, pada ketebalan rata-rata $(15 \mathrm{~cm})$. Adapun nilai modulus elastistas lapis pondasi bawah (E3) dan modulus elastisitas lapis tanah dasar (E4) semakin "lemah", dengan nilai masing-masing berkisar $30-7000 \mathrm{MPa}$ dan 30-2000 MPa dengan tebal lapisan masing-masing $20 \mathrm{~cm}$ dan $25 \mathrm{~cm}$. 
Tabel 1. Rekapitulasi Model Hubungan Antara Kondisi Fungsional dengan Kondisi Struktural

Sebagai Estimasi Kondisi Perkerasan pada Jalan Raya di Sulawesi Selatan dan Kalimantan

Selatan.

\begin{tabular}{|c|c|c|c|c|c|c|c|c|c|}
\hline Provinsi & $\begin{array}{c}\text { Lapisan } \\
\text { Perkerasan }\end{array}$ & $\begin{array}{c}\text { Jenis } \\
\text { Lapisan } \\
\text { Perkerasan }\end{array}$ & $\begin{array}{c}\text { Tebal } \\
\text { Lapisan } \\
\text { Perkerasan } \\
\text { (cm) }\end{array}$ & $\begin{array}{l}\text { Modulus } \\
\text { Elastisitas } \\
\text { (E) }(\mathbf{M P a})\end{array}$ & \multicolumn{2}{|c|}{ Persamaan Regresi } & $\left(\mathbf{R}^{2}\right)$ & (r) & $\begin{array}{c}\text { Tingkat } \\
\text { Hubungan }\end{array}$ \\
\hline \multirow{4}{*}{$\begin{array}{c}\text { Kalimantan } \\
\text { Selatan }\end{array}$} & $\begin{array}{c}\text { Lapis } \\
\text { Permukaan } \\
\text { (Surface) }\end{array}$ & $\mathrm{AC}$ & $5-24$ & $\begin{array}{l}1500- \\
30000\end{array}$ & $\begin{array}{l}\mathrm{E} 1= \\
2812,7 \mathrm{e}^{0,1555 I R I}\end{array}$ & Ekponesial & 0,2145 & 0,4631 & Sedang \\
\hline & $\begin{array}{c}\text { Lapis } \\
\text { Pondasi } \\
\text { Atas (Base) }\end{array}$ & $\begin{array}{c}\text { Aggregat } \\
\text { Batu Pecah } \\
\text { Kelas A }\end{array}$ & $10-20$ & $100-1500$ & $\begin{array}{lc}\mathrm{E} 2 \quad- \\
1,9846 I R I^{2} & + \\
65,367 I R I \quad+ \\
236,29\end{array}$ & Polinomial & 0,0779 & 0,2791 & Lemah \\
\hline & $\begin{array}{c}\text { Lapis } \\
\text { Pondasi } \\
\text { Bawah (Sub } \\
\text { Base) }\end{array}$ & $\begin{array}{c}\text { Aggregat } \\
\text { Sirtu Kelas } \\
\text { B } \\
\end{array}$ & $5-30$ & $30-1000$ & $\begin{array}{l}\text { E3 }= \\
204,89 \mathrm{e}^{0,06911 / R I}\end{array}$ & Eksponensial & 0,0386 & 0,1965 & $\begin{array}{l}\text { Sangat } \\
\text { Lemah }\end{array}$ \\
\hline & $\begin{array}{c}\text { Lapis } \\
\text { Tanah } \\
\text { Dasar } \\
\text { (Subgrade) }\end{array}$ & $\begin{array}{l}\text { Tanah } \\
\text { Merah }\end{array}$ & $5-85$ & $10-800$ & $\begin{array}{ll}\mathrm{E} 4 \quad- & - \\
2,4347 I R I^{2} & + \\
17,634 I R I & + \\
129,78 & \end{array}$ & Polinomial & 0,0074 & 0,086 & $\begin{array}{l}\text { Sangat } \\
\text { Lemah }\end{array}$ \\
\hline \multirow{5}{*}{$\begin{array}{c}\text { Sulawesi } \\
\text { Selatan }\end{array}$} & \multirow{2}{*}{$\begin{array}{c}\text { Lapis } \\
\text { Permukaan } \\
\text { (Surface) }\end{array}$} & HRS & 3 & \multirow{2}{*}{$\begin{array}{r}3000- \\
100 \\
000\end{array}$} & \multirow{2}{*}{$\begin{array}{l}\text { E1 }= \\
37,995 I R I^{2} \\
+10553 I R I \\
+7563,9\end{array}$} & \multirow{2}{*}{ Polinomial } & \multirow{2}{*}{0,5349} & \multirow{2}{*}{0,7314} & \multirow{2}{*}{ Kuat } \\
\hline & & ATB & $4-5$ & & & & & & \\
\hline & $\begin{array}{c}\text { Lapis } \\
\text { Pondasi } \\
\text { Atas (Base) }\end{array}$ & $\begin{array}{c}\text { Aggregat } \\
\text { Kelas A }\end{array}$ & 15 & $100-60000$ & $\begin{array}{l}\mathrm{E} 2= \\
2412,5 \mathrm{e}^{0,2037 I R I}=\end{array}$ & Eksponensial & 0,1731 & 0,4167 & Sedang \\
\hline & $\begin{array}{c}\text { Lapis } \\
\text { Pondasi } \\
\text { Bawah (Sub } \\
\text { Base) } \\
\end{array}$ & $\begin{array}{c}\text { Aggregat } \\
\text { Kelas B }\end{array}$ & 20 & $30-7000$ & $\begin{array}{ll}\mathrm{E} 3 \quad= & - \\
128,71 I^{2} I^{2} & + \\
1506,8 I R I & - \\
2100,4 & \end{array}$ & Polinomial & 0,0905 & 0,3008 & Lemah \\
\hline & $\begin{array}{c}\text { Lapis } \\
\text { Tanah } \\
\text { Dasar } \\
\text { (Subgrade) }\end{array}$ & Subgrade - & 25 & $30-2000$ & $\begin{array}{l}\mathrm{E} 4= \\
66,905 \mathrm{e}^{0,1372 I R I}=\end{array}$ & Ekspnensial & 0,0722 & 0,2687 & Lemah \\
\hline
\end{tabular}

Karakteristik lapisan $A C$ yang lebih peka terhadap variasi kadar aspal maupun variasi gradasi agregat, menunjukkan desain lapisan $A C$ biasanya didesain untuk melayani lalu lintas kendaraan berat, dibandingkan dengan lapisan $H R S$ dengan tebal penggelaran minimum $3 \mathrm{~s} / \mathrm{d}$ $4 \mathrm{~cm}$. Lapis HRS tersebut biasanya digunakan sebagai lapis permukaan konstruksi jalan yang melayani lalu lintas kendaraan yang sedang, dengan didukung lapis ATB. Ruas jalan yang diteliti merupakan Jalan Nasional dengan volume dan kecepatan yang tinggi. Hal tersebut juga mengindikasi ruas jalan dengan lapis perkerasan permukaan $A C$ (Asphalt Concrete) lebih kuat menahan beban yang diberikan, sehingga ketika diuji dengan alat $F W D$ dengan transfer beban yang setara, lendutan rata - rata yang dihasilkan tidak sampai mempengaruhi lapisan perkerasan di bawahnya. Berbeda dengan lapis perkerasan permukaan HRS (Hot Rolled Sheet) yang didukung lapis ATB (Asphalt Threated Base), yang apabila diuji 
dengan alat $F W D$ dengan transfer beban yang setara, lendutan rata-rata yang dihasilkan mampu mempengaruhi lapisan perkerasan di bawahnya.

\section{KESIMPULAN DAN SARAN}

\section{Kesimpulan}

1. Berdasar kondisi perkerasan dari ruas-ruas jalan di Provinsi Kalimantan Selatan, nilai kekasaran permukaan (IRI) memiliki korelasi yang cukup untuk memprediksi modulus elastisitas lapis permukaan (E1), akan tetapi kurang berkorelasi lapis pondasi atas (E2), dan tidak berkorelasi dengan kondisi struktur lapis pondasi bawah (E3) dan lapis tanah dasar (E4). Pada Provinsi Sulawesi Selatan, nilai IRI memiliki korelasi yang baik dengan modulus elastisitas lapis permukaan (E1), dan cukup berkorelasi dengan modulus elastisitas lapis pondasi atas (E2), namun kurang berkorelasi dengan modulus elastisitas lapis pondasi bawah (E3) dan modulus elastisitas lapis tanah dasar (E4).

2. Modulus elastisitas (E) lapisan juga dipengaruhi oleh jenis dan tebal lapisan perkerasan. Lapis permukaan dengan bahan $A C$, dengan ketebalan yang lebih besar mengindikasi besaran lendutan cukup mempengaruhi lapisan permukaan atas, akan tetapi semakin melemah sehingga tidak mempengaruhi ke lapis perkerasan di bawahnya. Lapis permukaan dengan material $H R S$ (Hot Rolled Sheet) dengan ketebalan yang relatif lebih tipis mengindikasi besaran lendutan lebih mempengaruhi lapisan permukaan atas, dan berlanjut ke lapisan pondasi atas, dan semakin melemah dan tidak sampai mempengaruhi lapis perkerasan bawah.

\section{Saran}

Pengukuran nilai IRI dan lendutan dengan $F W D$ sebaiknya dilakukan dalam rentang waktu yang berdekatan dan pada masing-masing lajur jalan dengan ketelitian jarak yang relatif sama.

\section{DAFTAR PUSTAKA}

Amrullah, K., 2013, Jenis Campuran Aspal Pada Lapisan AC - WC, Blog Khammal, Bandah Aceh.

Hardwiyono, S., 2012, Perhitungan Tebal Setara Metode BoussinesqExcel dan FWD-ELMOD pada Perkerasan Lentur, Universitas Muhammadiyah Yogyakarta, Yogyakarta.

Kartika, A. A. G., Widyastuti, H., Herijanto, W., Buana, C., \& Arif, P. C., 2006, Validasi Persamaan Korelasi antara NIlai International Roughness Index (IRI) dengan nilai kerusakan (NK) Jalan (Studi Kasus Jalan Tol Surabaya Gempol), Jurnal Transportasi edisi Juni 2006, Forum Studi Transportasi Perguruan Tinggi.

Kementerian Pekerjaan Umum, 2009, Prediksi Tebal Lapisan Beraspal Menggunakan Data Lendutan FWD dan Metode Neural Network untuk Single Layer Perceptron, Kementerian Pekerjaan Umum, Bandung.

Kementerian Pekerjaan Umum, 2011, Panduan Survai Kondisi Jalan, No. SMD 03/RCS, Kementerian Pekerjaan Umum, Jakarta.

Paterson, W.D.,1987, The Highway Design and Maintenance Standard Series - Road Deterioration and Maintenance Effects, A World Bank Publication - The John Hopkins University Press -Baltimore.

Perera, R.W. and S.D. Kohn., 1998, LTPP Data Analysis: Factors Affecting Pavement Smoothness, NCHRP Web Document 40, Transportation Research Board, National Research Council, Washington, D.C. 
Prabowo, G. D., Rahmawati, V. D., Djakfar, L., dan Wicaksono, A., 2013. Studi Hubungan Antara Nilai Kerusakan Permukaan Jalan (PCI) Dengan Nilai Ketidakrataan Jalan (IRI) (Studi Kasus : Jalan Provinsi Di UPT Mojokerto), Jurusan Teknik Sipil, Universitas Brawijaya Malang

Suherman, 2008, Studi Persamaan korelasi antara Ketidakrataan Permukaan Jalan dengan Indeks Kondisi Jalan, Studi Kasu Ruas Jalan Labuan-Cibalung, Jurnal Teknik Sipil, Volume 8 No. 3, Juni 2008: $206-214$
Utama, R.M., dan Farida, I., 2016, Evaluasi Kondisi struktural pada Jalan Berdasarkan Hubungan antara Ketidakrataan Permukaan Permukaan Jalan (IRI) dan Indeks Kondisi Jalan $(R C I)$ (Studi Kasus Ruas Jalan Selajambe-Cibogo-Cibeet, Cianjur, Jurnal Sekolah Tinggi teknik (STT) Garut, Vol. 14 No. 1.

Zeahsa, I., 2015, Model Hubungan International Roughness Index (IRI) dan Surface Distress Index (SDI) pada Perkerasan Lentur Jalan Raya, Tesis Magister Teknik Sipil, Universitas Syiah Kuala, Banda Aceh Darussalam. 